University of Windsor

Scholarship at UWindsor

$1-1-1966$

\title{
Studies on the conformational changes of mitochondrial malate dehydrogenase in urea-phosphate solutions.
}

\author{
Robert Joseph Seguin \\ University of Windsor
}

Follow this and additional works at: https://scholar.uwindsor.ca/etd

\section{Recommended Citation}

Seguin, Robert Joseph, "Studies on the conformational changes of mitochondrial malate dehydrogenase in urea-phosphate solutions." (1966). Electronic Theses and Dissertations. 6447.

https://scholar.uwindsor.ca/etd/6447

This online database contains the full-text of PhD dissertations and Masters' theses of University of Windsor students from 1954 forward. These documents are made available for personal study and research purposes only, in accordance with the Canadian Copyright Act and the Creative Commons license-CC BY-NC-ND (Attribution, Non-Commercial, No Derivative Works). Under this license, works must always be attributed to the copyright holder (original author), cannot be used for any commercial purposes, and may not be altered. Any other use would require the permission of the copyright holder. Students may inquire about withdrawing their dissertation and/or thesis from this database. For additional inquiries, please contact the repository administrator via email (scholarship@uwindsor.ca) or by telephone at 519-253-3000ext. 3208. 


\section{STUDIES ON THE CONFORMATIONAL CHANGES \\ OF MITOCHONDRIAL MALATE DEHYDROGENASE \\ IN UREA-PHOSPHATE SOLUT IONS}

BY

ROBERT JOSEPH SEGUIN, C. S. B.

\section{A Thesis \\ Submitted to the Faculty of Graduate Studies through the \\ Department of Chemistry in Partial Fullfillment of the Requirements for the Degree of Master of Science at the \\ University of Windsor}

Windsor, Ontario

1966 
UMI Number: EC52628

\section{INFORMATION TO USERS}

The quality of this reproduction is dependent upon the quality of the copy submitted. Broken or indistinct print, colored or poor quality illustrations and photographs, print bleed-through, substandard margins, and improper alignment can adversely affect reproduction.

In the unlikely event that the author did not send a complete manuscript and there are missing pages, these will be noted. Also, if unauthorized copyright material had to be removed, a note will indicate the deletion.

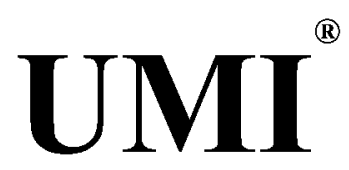

\section{UMI Microform EC52628}

Copyright 2008 by ProQuest LLC.

All rights reserved. This microform edition is protected against unauthorized copying under Title 17, United States Code.

ProQuest LLC

789 E. Eisenhower Parkway

PO Box 1346

Ann Arbor, MI 48106-1346 
THIS THESIS HAS BEEN EXAMINED AND APPROVED BY:

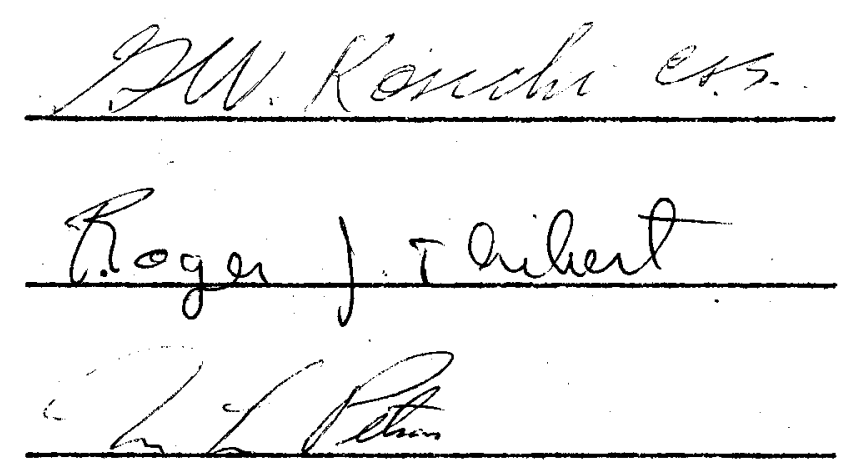

152224 


\section{ABSTRACT}

Pig heart mitochondrial malate dehydrogenase is gradually inactivated in $4 \mathrm{M}$ urea. During the inactivation, sulfhydryl groups on the protein are exposed in a first order reaction. The reaction is followed spectrophotometrically using the sulfhydryl reagent 5, 5'-dithiobis-(2-nitrobenzoate). Titration with this reagent in the presence of urea exposes ten to twelve sulfhydryl groups per molecule of mitochondrial malate dehydrogenase. The enzyme is also inactivated when diluted in water but no sulfhydryl groups are unmasked. The loss of activity and the appearance of sulfhydryl groups in urea solutions do not take place at the same rate.

The conformational changes of malate dehydrogenases that occur in urea solutions are partially prevented by inorganic phosphate ions and, less so, by the substrates of the enzyme. When the enzyme is pre-incubated with the substrates the final total absorbancy of the enzyme in the presence of urea and DTNB is reduced by about fifteen per cent. 


\section{ACKNONLEDGMENTS}

I would like to thank and gratefully acknowledge the direction of Father George W. Kosicki, C. S. B., Ph. D., who encouraged, guided, and inspired me to the completion of this work.

I would also like to thank Dr. R. J. Thibert and Dr. M. I. Petras for their assistance and welcome criticisms.

I am grateful also to the Ontario Research Foundation (Department of University Affairs) for the financial assistance given me. 
TABLE OF CONTENTS

page

ABSTRACT............................ 11

ACKNOWLEDGMENTS..........................11

IIST OF TABLES.................... v

LIST OF FIGUHES....................... vi

TABLE OF NOMENCLATURE................... vii

Chapter

I INTRODUCTION..................... I

II Methods and Materials............... 5

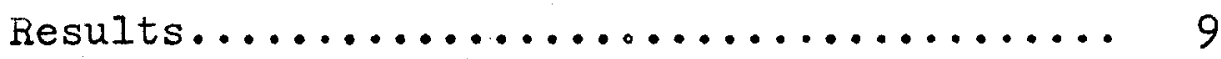

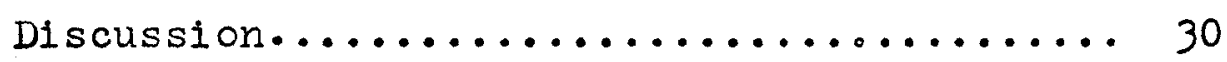

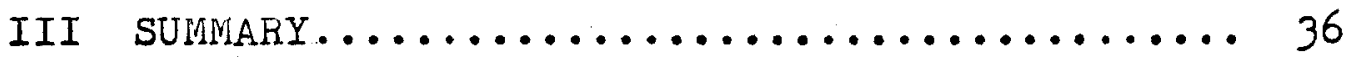

BIBLIOGRAPHY............................. 38

VITA AUCTORIS......................... 40 


\section{LIST OF I'ABIES}

\section{Table}

I SH Appearance in $4 \mathrm{M}$ Urea

in the Presence of Phosphate.......... 13

II Comparison of the Effect of Phosphate

Ions on $\mathrm{SH}$ Appearance and Activity

Loss at Higher Urea Concentrations....... 26

III Effect of Substrates on Protection of Activity and $\mathrm{SH}$ Appearance in

$4 \mathrm{M}$ Urea........................... 28

IV SH Appearance in $4 \mathrm{M}$ Urea in the Presence of NADH................ 29 


\section{LIST OF FIGURES}

Figure

1. The Observed First Order Rate

Plot for SH Appearance................ 12

2. The Observed First Orden Rate

Constants as a Function of Urea

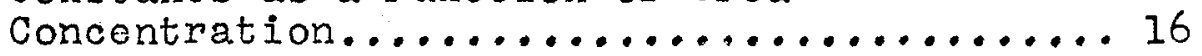

3. The Observed First Order Rate

Constant as a Function of Urea

Concentration (SH assay system

4. MDH Activity Loss with and without

Potassium Phosphate in 4 Mrea........... 22

5. MDH Activity Loss Compared to $\mathrm{SH}$

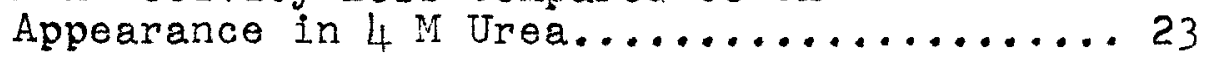

6. The Activity of MDH in Urea and

Phosphate as a Function of pH........... 25

$v i$ 


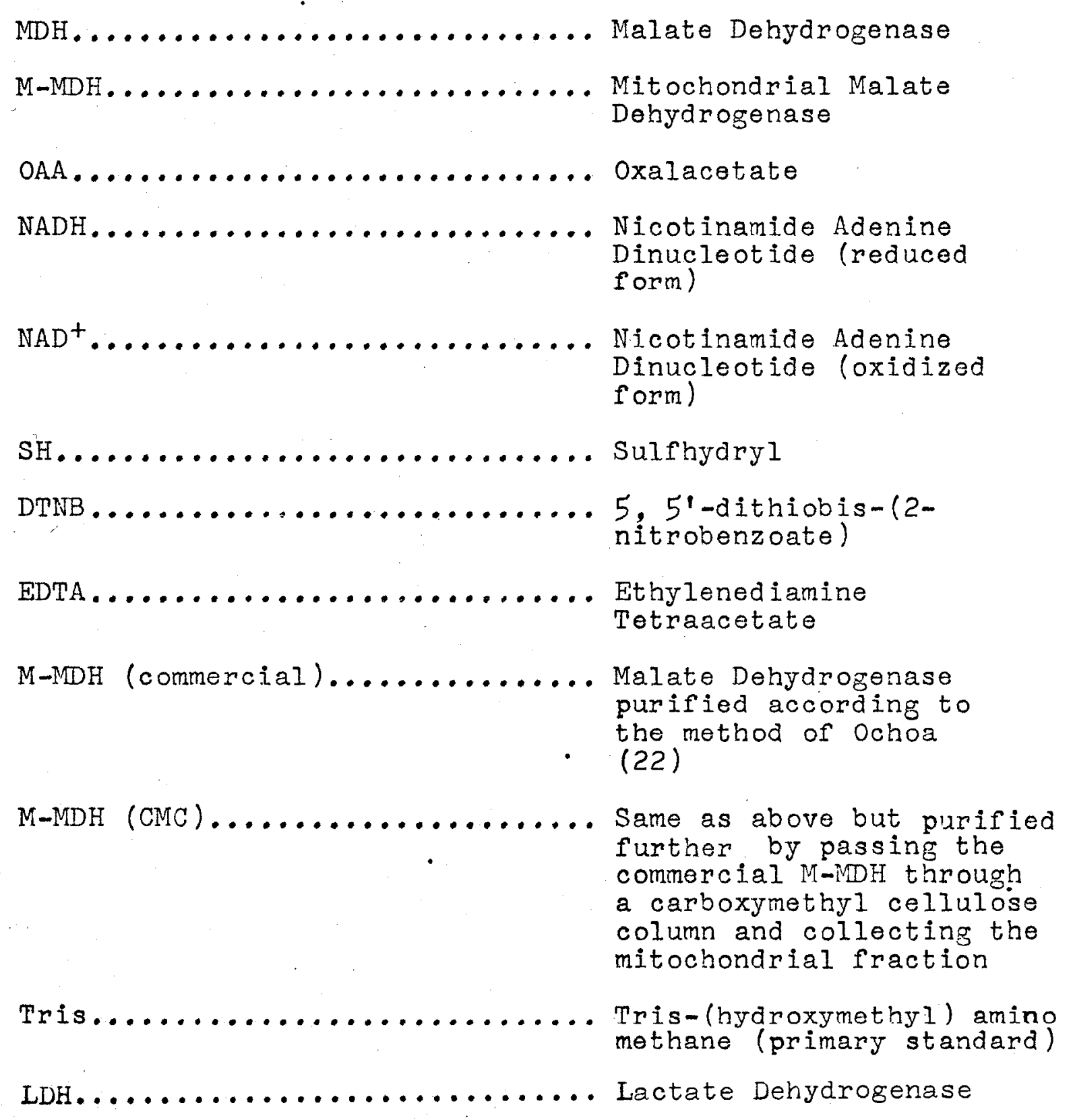

vii 
CHAPTER I

INTRODUCT ION

Malate dehydrogenase catalyzes the following reaction: -<smiles>[R]N1[C+]=CC([CH+])C(C(N)=O)=C1</smiles>

(OAA)

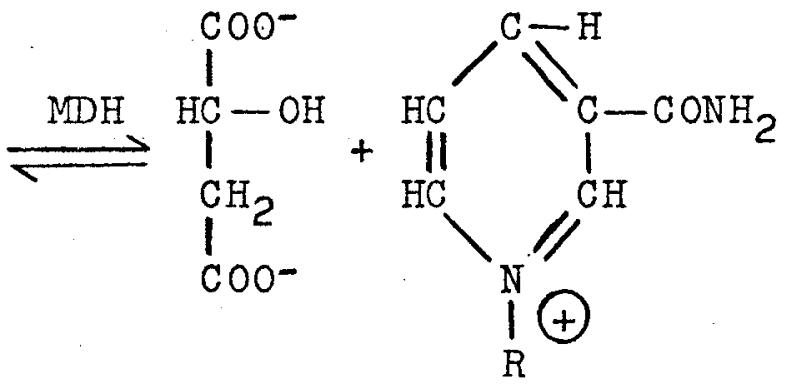

Thorne and Kaplan (I) have reported that about 35 to 40 per cent of pig heart mitochondrial malate dehydrogenase (M-MDH) is in the helical form with no disulfide bridges. The optical rotary dispersion studies made by Joyce and Grisolia (2) suggest that M-MDH is a highly coiled protein and that the enzyme activity is possibly related to the percentage of coiling. Thorne and Kaplan (I) studied the enzyme in the presence of urea and gave a value of 14 sulfhydryl (SH) groups per molecule of pig heart M-MDH. This was determined by titration with p-hydroxymercuribenzoate assuming a molecular weight of 70,000 grams per mole for M-MDH. Siegel and Englard (3) reported 10 to $13 \mathrm{SH}$ groups 
per mole of beef heart $M-M D H$ using various sulfhydryl reagents and assuming a molecular weight of 65,000 grams per mole. They found that these SH groups of beef heart M-MDH were not readily accessjble to SH reagents, unless the protein was denatured with urea.

Conformational changes of enzymes have been studied by the appearance of masked sulfhydryl (SH) groups under a variety of conditions (4-13). Some SH groups react immediately with $S H$ reagents while others are protected in the folds of the protein in such a way that they are not available for reaction with these reagents. These "buried". SH groups can be made available for reaction if the protein configuration is changed by such agents as urea or detergents. Such masked SH groups have been reported for the citrate condensing enzyme (13).

Urea denaturation of proteins is a very complicated process, which is not clearly understood. Its effect is probably twofold. The first is that urea readily forms urea-water clusters at the expense of the structured water around the protein. Urea, thus, "melts" the hydrated water which participates in tertiary protein structure in aqueous solutions (14).

On the other hand, Robinson and Jencks (15, 16) have shown that the denaturation of proteins by urea solutions cannot be attributed solely to the hydrophobic effects of 
urea. Using acetyltetraglycine ethyl ester and determining activity coefficients for various solvents including urea they found that acetyltetraglycine ethyl ester became more soluble as they increased the urea concentration. From these studies they concluded that urea decreases the activity coefficients of exposed amide and peptide groups in the denatured protein. Thus, a major part of the denaturing activity of urea toward some proteins could be accounted for by an interaction of urea with peptide and amide groups of the protein by a "nonhydrophobic" mechanism.

The effects of salts on conformationa]. changes of enzymes have also been examined $(5,13,17,18)$. Chilson et al. $(19,20)$ have found in reversible inactivation studies with different proteins that salts protect against inactivation and aid in the reactivation of many dehydrogenases. The protective effect of salts and substrates against activity loss upon lyophilization, dialysis, and dilution of pig heart $M-M D H$ was also demonstrated (2).

This thesis is a report on the unmasking of SH groups In pig heart mitochondrial malate dehydrogenase on treatment of the enzyme in urea solutions. The appearance of $\mathrm{SH}$ groups are measured with 5, 5'-dithiobis-(2-nitrobenzoate) DTNB (21). 


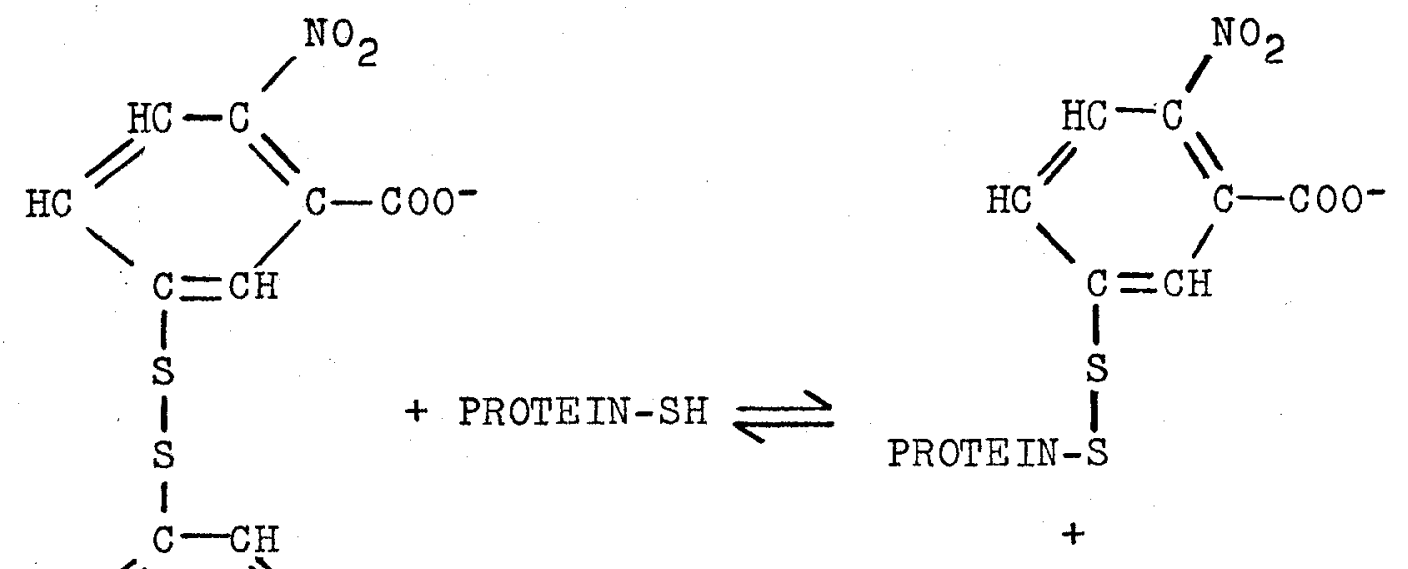

(DTNB)

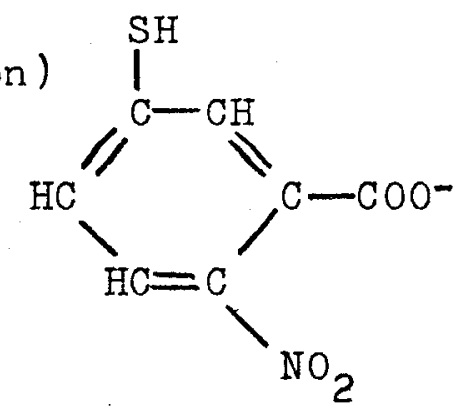

In the presence of protein $\mathrm{SH}$ groups, this reagent undergoes the above reaction under slightly basic conditions. The mercaptide anion which forms has an absorbance maximum at $4.12 \mathrm{~m} \mu$.

The enzyme is partially protected against activity loss in urea solution by potassium phosphate and the substrates of $\mathrm{MDH}$. The substrates of $\mathrm{MDH}$ also protect against complete sulfhydryl appearance when the mitochondrial enzyme is treated with urea. 
CHAPTER II

\section{Methods and Materials}

Pig heart mitochondrial malate dehydrogenase (M-MDH) from C. F. Boehringer and Son, Mannheim, prepared according to Ochoa (22), was used for part of the studies. In this preparation, which will be referred to as commercial M-MDH, there is some contamination by the presence of supernatant (cytoplasmic) MDH. Some commercial M-MDH was purified further by passing it through a carboxymethyl cellulose column thereby removing any of the supernatant $\mathrm{MDH}$, that was present. This preparation will be referred to as $M-M D H ~(C M C) ~(23)$. Both preparations of $M-M D H$ were stored at $0^{\circ} \mathrm{C}$ as a suspension in an ammonium sulfate solution (Fisher Scientific).

The determination of the concentration of $M-M D H$ was based on the extinction coefficients for enolase and nucleic acid of Warburg and Ghristian (24). The optical density of a protein solution was read at 260 and $280 \mathrm{~m} \mu$ and the protein concentration was determined using a nomograph prepared by E. Adams and distributed by the California Corporation for Biochemical Research. 
The enzyme was assayed for activity by determining the rate of oxidation of NADH at $340 \mathrm{m \mu}$ and $25^{\circ} \mathrm{C}$. The solutions used in this assay were neutralized with $\mathrm{KHCO}_{3}$. They were prepared fresh daily and kept at $00^{\circ} \mathrm{C}$ until they were used. NADH, OAA, and serum albumin were purchased from C. F. Boehringer and Son, Mannheim. Tris, $\mathrm{KHCO}_{3}$, and potassium phosphate were obtained from Fisher Scientific.

In the assay for $\mathrm{MDH}$ activity, each cuvette $10.5 \mathrm{~cm}$ light path) contained $67 \mathrm{mM}$. Tris-acetate buffer, $\mathrm{pH}$ 7.4, 93.5 $\mu \mathrm{M}$ NADH, $5.06 \mathrm{mM} \mathrm{OAA}$ and the appropriate dilution of M-MDH. The $\mathrm{M}-\mathrm{MDH}$ was diluted in serum albumin ( $\mathrm{mg} / \mathrm{ml}$ ), $0.02 \mathrm{M}$ potassium phosphate, $\mathrm{pH} 7.4$. The activity is expressed as the number of umoles of $\mathrm{NADH}$ oxidized per minute.

M-MDH was assayed for $\mathrm{SH}$ appearance by measuring the 412 ma absorbance increase of DTNB in the presence of the enzyme and urea. The mercaptide anion that is formed has an absorption maximum of 412 mja and a molar absorbancy of 13,600 (21). The DTNB was purchased from Aldrich Chemical Co., Inc. The DTNB solutions which were prepared fresh daily were made up in buffer solutions at the appropriate concentration and $\mathrm{pH}$. The assays for SH appearance were carried out at $25^{\circ} \mathrm{C}$. Since the mercaptide ion, 5-thio-(2nitrobenzoate) is readily reoxidized to its disulfide form 
in the presence of metal ions such as copper and iron ions, ethylenediamine tetraacetate (EDTA) (Calbiochem) a chelating agent was added to some of the assay systems. To ensure a final total absorbancy reading, EDTA was routinely added to the cuvettes when M-MDH (CMC) was used.

Reagent grade urea (British Drug House, Ltd.) solutions were used for the experiments with commercial MDH. Ultra Pure urea, M. A. (Mann Research Iabs) was used in the experiments with M-MDH (CMC). Urea solutions were prepared fresh daily.

In the SH assay system \#I each cuvette $(1 \mathrm{~cm}$ Iight path) contained the indicated concentration of urea, $1 \mathrm{mM}$ DTNB neutralized with $10 \mathrm{mM}$ potassium phosphate, $\mathrm{pH} 7.3$, and $0.45 \mu \mathrm{M} \mathrm{M-MDH}$ (commercial).

In the SH assay system \#2 each cuvette $(1 \mathrm{~cm}$ light path) contained the indicated concentration of urea, $1 \mathrm{mM}$ DTNB neutralized with $0.1 \mathrm{M}$ potassium phosphate, $\mathrm{pH} 6.8$, the indicated concentration of EDTA, and $0.314 \mu \mathrm{M} M-M D H$ (CMC). The final pH of this system was $7.35 \pm 0.05$.

Any variations of these systems are indicated in the legends. Controls containing everything except the enzyme were carried out for each reaction. 
SH appearance is expressed as the log $a / a-x$, where " $a$ " is the final total absorbance measured at the end of the reaction and " $x$ " is the total absorbance at any particular time during the reaction. The first order rate constant " $k$ " is obtained by the equation:

$$
k=\frac{2.303(\log 2 / a-x)}{t}
$$

$\mathrm{SH}$ appearance is also expressed as the $\log \% \mathrm{SH}$ appearance. This represents the $\log \%$ unreacted SH groups. Another expression that is used is \% $\mathrm{SH}$ appearance. This refers to the \% reacted SH groups.

In the substrate protection studies controls for each substrate were carried out and used as standards in obtaining the final total absorbance. This was done to correct for the substrate-DTNB interaction. The substrates $\mathrm{NAD}^{+}$and I-Malate were purchased from C. F. Boehringer and Son, Mannheim, and Sigma Chemical Co., respectively.

Distilled and deionized water was used in the preparation of all the solutions. The various reactions were followed by using either the 0.0 to 0.1 or the 0.0 to 0.2 absorbancy scales of the Gilford model 2000 absorbancy recorder attachment to a Becleman manochromator equipped with thermospacers set at $25^{\circ} \mathrm{C}$. The $\mathrm{pH}$ of the reaction cells were measured previous to or at the end of the assays by a Beckman Model $G$ pH meter. 


\section{Results}

The SH groups of M-MDH (commercial) in aqueous solutions do not react with D'INB in the presence or absence of potassium phosphate buffer, $\mathrm{pH} 7.4$, but they do react in the presence of urea. The SH groups of $M-M D H(C M C)$ react very slowly with DTNB in aqueous solution in the presence of potassium phosphate buffer, $\mathrm{pH}$ 7.4. Less than one sulfhydryl group is exposed after a one hour incubation. However all the SH groups are exposed very quickly and react with the DTNB in the presence of urea. Figure 1 shows the observed first order plot of the appearance of $\mathrm{SH}$ groups. The behaviox of pig heart $M-M D H$, observed here is similar to that described by Siegel and Englard for beef heart mitochondrial MDH (3). These worliers used a variety of $\mathrm{SH}$ reagents, but were not able to follow the kinetics of SH appearance because of the limitations of the reagents they were using.

Figure 1 shows the observed first order plot of the appearance of SH groups as measured by the increase in absorbance of $412 \mathrm{~m} \mu$ in the presence of urea, 0.01 M DTNB, and $10 \mathrm{mM}$ potassium phosphate buffer, $\mathrm{pH} 7.4$. The average observed first order rate constants for 
the reactions in $7.2 \mathrm{M}$ urea and $4.0 \mathrm{M}$ urea are 0.99 $\min ^{-1}$ and $0.126 \mathrm{~min}^{-1}$, respectively. In the presence of $10 \mathrm{mM}$ EDTA, and $0.1 \mathrm{M}$ potassium phosphate, at a final $\mathrm{pH}$ of $7.4, \mathrm{M}-\mathrm{MDH}$ (CMC) reacted with DTNB very slowly. The observed first order rate constant for this reaction was $0.013 \mathrm{~min}^{-1}$ (Table I). First order plots for the appearance of SH groups were observed for MDH (GMC) in the presence of urea, $10 \mathrm{mM} \mathrm{EDTA}$, and $0.1 \mathrm{M}$ potassium buffer at a final pH of 7.4 .

The observed first order rate constant as a function of urea concentration is show in figures 2 and 3 . The data are taken from several experiments using different concentrations of urea. Figure 2 represents the data from experiments using different samples of commercial $\mathrm{M}-\mathrm{MDH}$, while figure 3 is taken from reactions of $\mathrm{M}-\mathrm{MDH}$ (CMC) in urea solutions. The observed first order rate constant increases logarithmically with increasing urea concentrations.

From experiments using $\mathrm{M}-\mathrm{MDH}$ (CMC) in the presence of urea, $10 \mathrm{mM}$ EDTA, I mM DTNB neutralized with $0.1 \mathrm{M}$ potassium phosphate it was observed that the final total absorbancy at $412 \mathrm{m \mu}$ did not vary with the concentration of urea present during the reaction (3.2 to 6.4 M urea). 
Legend to Figure I The Observed First Order Rate Plot for SH Appearance

The above reactions were carried out using SH assay system \# 1 , containing either $4 \mathrm{M}$ or $7.2 \mathrm{M}$ urea. 


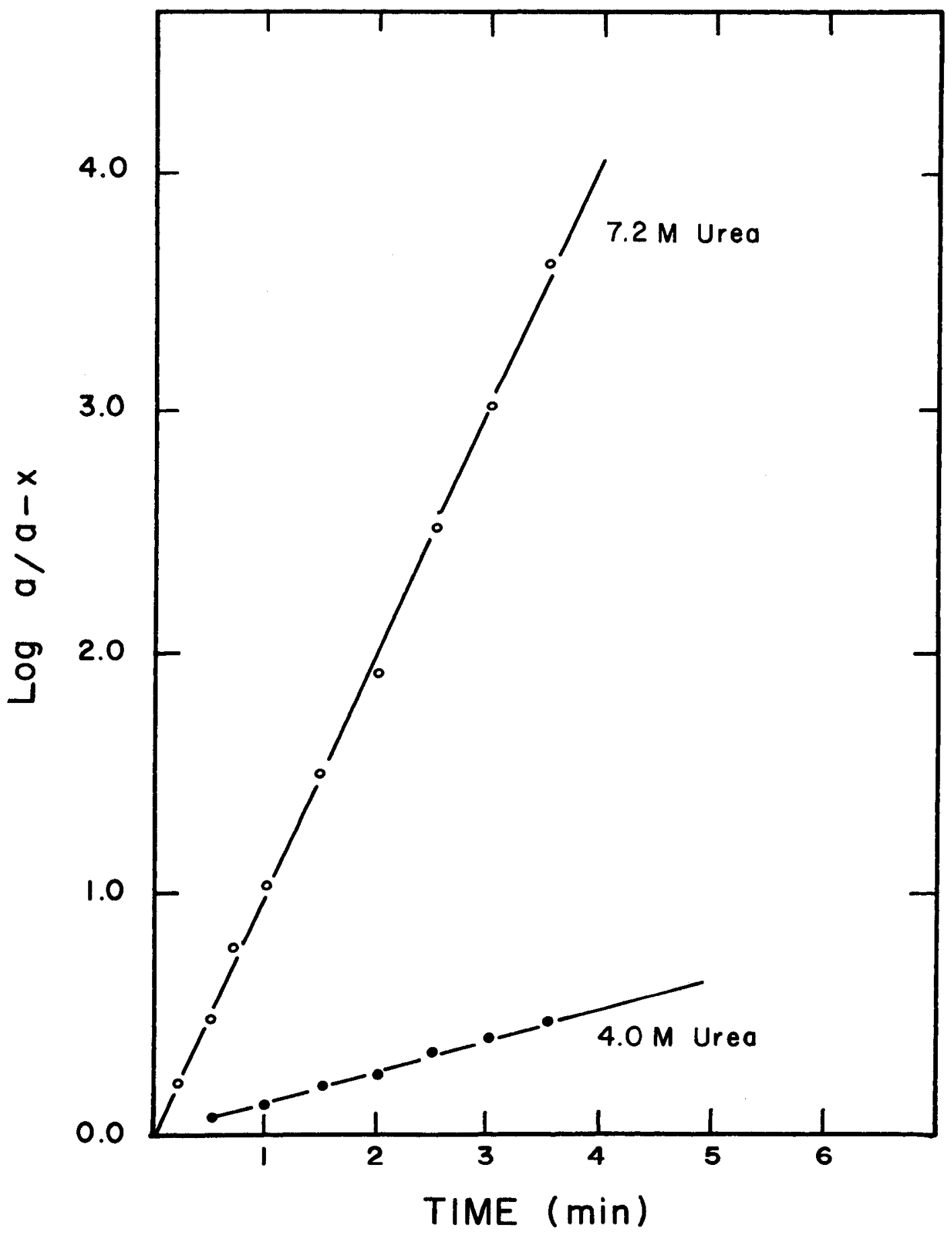




\title{
TABLE I
}

\author{
SH APPEARANCE IN 4 M UREA IN THE \\ PRESENCE OF PHOSPHATE
}

\begin{tabular}{lcc} 
& \multicolumn{2}{c}{ Observed First $\frac{\text { Order Rate Constant }}{(412 \mathrm{m \mu})}$} \\
& $\mathrm{min}^{-1}$ & $\min ^{-1}$ (EDTA*) \\
Complete System & 0.192 & \\
$10 \mathrm{mM}$ Potassium Phosphate & 0.108 & - \\
0.1 M Potassium Phosphate & 0.055 & 0.062 \\
- Urea & 0.000 & 0.013
\end{tabular}

\section{Legend:}

The complete system was $2.8 \mu \mathrm{M} M-M D H$ (commercial, dialyzed) I mM DTNB neutralized to $\mathrm{pH} 7.4$ with $\mathrm{NaOH}, 4 \mathrm{M}$ urea. The potassium phosphate added was pH 7.4 .

* SH assay system \# 2, $4 \mathrm{M}$ urea, $10 \mathrm{mM}$ EDTA. 
At the higher concentrations of urea there is a wide range of values for the observed first order rate constant. Therefore, for the following studies, $4 \mathrm{M}$ urea concentrations are used. Also, the slower denaturation allows the measurement of concommitant activity loss.

M-MDH (CMC) was titrated with DTNB in the presence of $0.1 \mathrm{M}$ potassium phosphate, $10 \mathrm{mM}$ EDTA, and $4 \mathrm{M}$ urea at a final $\mathrm{pH}$ of 7.4 . By plotting the final total absorbancy $(412 \mathrm{~m} \mu$ ) as a function of DTNB concentration, It was found that there were from 10 to. $12 \mathrm{SH}$ groups per molecule of $M D H$ (CMC).

The activity of $M-M D H$ is gradually lost in the presence of $4 \mathrm{M}$ urea. In the presence of phosphate ions the loss of activity takes place at a much slower rate in $4 \mathrm{M}$ urea solutions. Figure 4 shows the effect of the time of incubation on the loss of activity, in the presence of and in the absence of phosphate ions. Phosphate ions also reduce the observed first order rate constants for $\mathrm{SH}$ appearance in $4 \mathrm{M}$ urea (Table I). Figure 5 shows the effect of the time of incubation in $4 \mathrm{M}$ urea both on the loss of activity and on the appearance of SH groups. These two phenomena do not coincide but both can be varied by the addition of phosphate ions. It is also noticeable that potassium 
Legend to Figure 2 The Observed First Order Rate Constants as a Function of Urea Concentration

The above reactions were carried out using SH assay system \# 1 , containing the designated amounts of urea. " $k$ " represents the observed first order rate constant as described in the methods. 


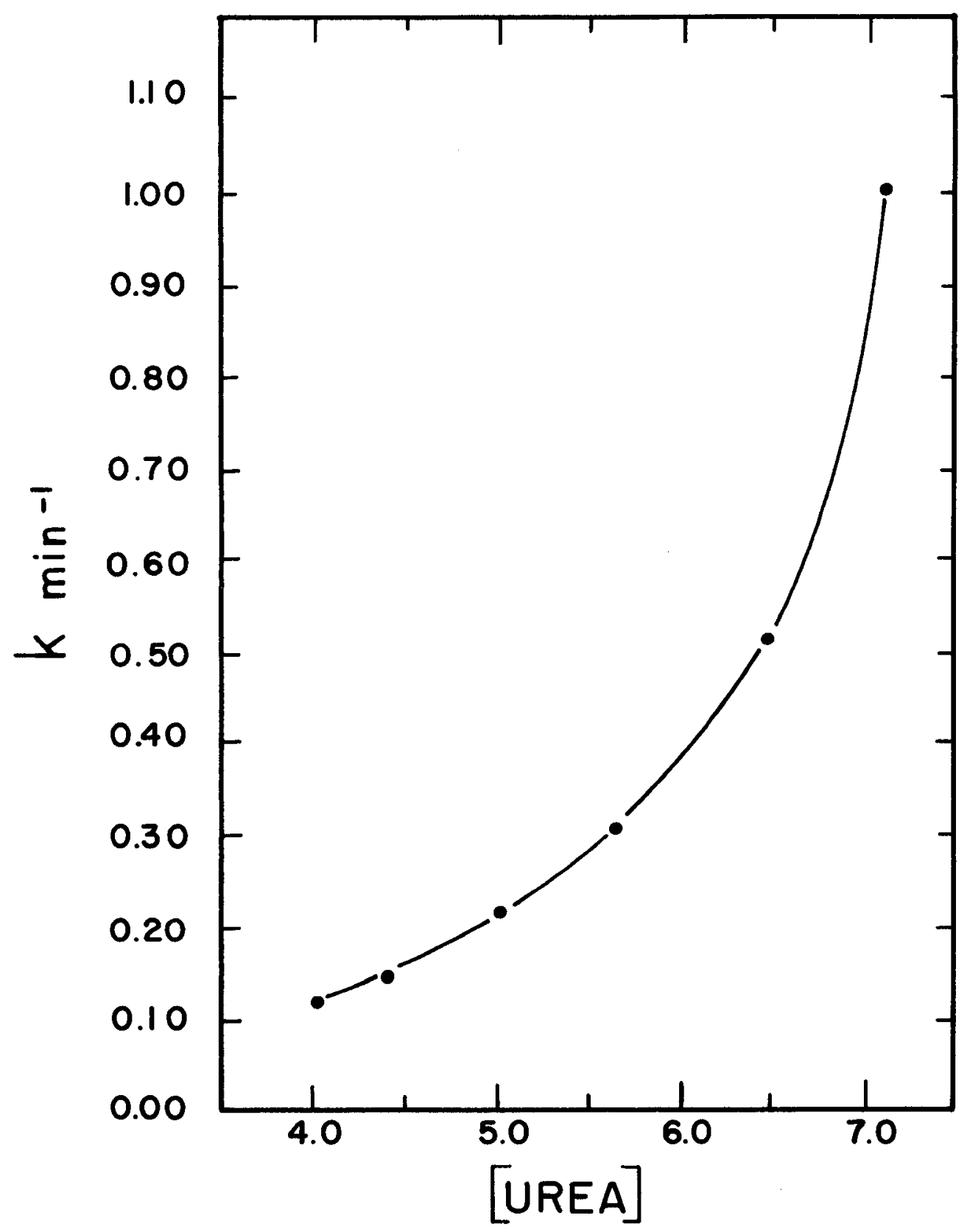


Legend to Figure 3 The Observed First Order Rate Constant as a Function of Urea Concentration (SH assay system \#2)

The above reactions were carried out using SH assay system \#2, containing $10 \mathrm{mM}$ EDTA and the designated amounts of urea. 


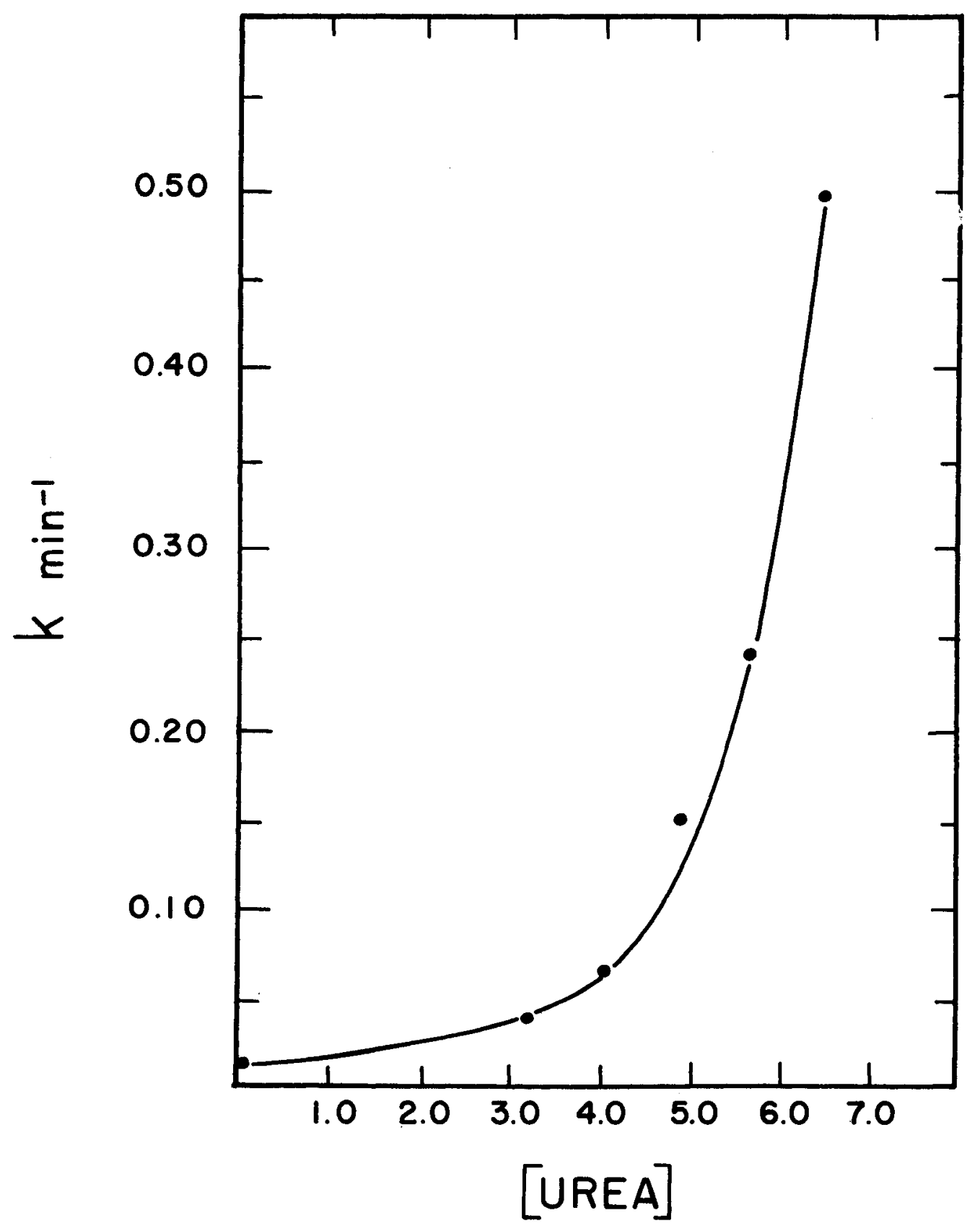


phosphate is more effective as a protecting agent against inactivation than against $\mathrm{SH}$ appearance. The maximum protection against activity loss in the presence of phosphate ions is between pH 7.0 and 7.5 in both dilute water and urea solutions (Figure 6). Protection by potassium phosphate against activity loss and against $\mathrm{SH}$ appearance can be observed even in higher concentrations of urea (cf. Table II).

The presence of the substrates $\mathrm{NADH}, \mathrm{NAD}^{+}$, and $\mathrm{OAA}$ show some protection against activity loss in the presence of $4 \mathrm{M}$ urea and $10 \mathrm{mM}$ potassium phosphate (Table III). The presence of these substrates and, also, L-malate during urea unmasking decreases the final total absorbancy about 15\%. This is equivalent to two less SH groups exposed per molecule of $\mathrm{M}-\mathrm{MDH}$ upon treatment of the enzyme with urea. These studies were done in the presence of $10 \mathrm{mM}$ potassium phosphate; $0.1 \mathrm{M}$ potassium phosphate, $1 \mathrm{mM} \mathrm{EDTA}$; and, $10 \mathrm{mM}$ Tris-HCl. In each case similar results were obtained (Table III).

The presence of NADH reduces the first order rate constant (Table IV). This effect was also obtained in the same system as that described in the legend of Table IV, but using $5 \mathrm{M}$ urea. In both cases the observed first order rate constant is reduced by about $50 \%$. 
Legend to Figure 4 MDH Activity Loss with and without Potassium Phosphate in 4 Mrea

Mixtures containing 0.45 MM M-MDH (commercial) were incubated at $25^{\circ} \mathrm{C}$ in $\left.\mathrm{A}\right) 4 \mathrm{M}$ urea, B) $4 \mathrm{M}$ urea, $1 \mathrm{mM}$ DTNB neutralized with $10 \mathrm{mM}$ potassium phosphate, and having a final pH of 7.3 , C) $4 \mathrm{M}$ urea, $10 \mathrm{mM}$ potassium phosphate with a final $\mathrm{pH}$ of $7 \cdot 3$. Curves $\mathrm{A}), \mathrm{B}$ ), and $\mathrm{C}$ ) show activity assays (expressed as $\log \%$ activity) measured by periodic aliquots, using the oxidation of NADH as described in the methods. 


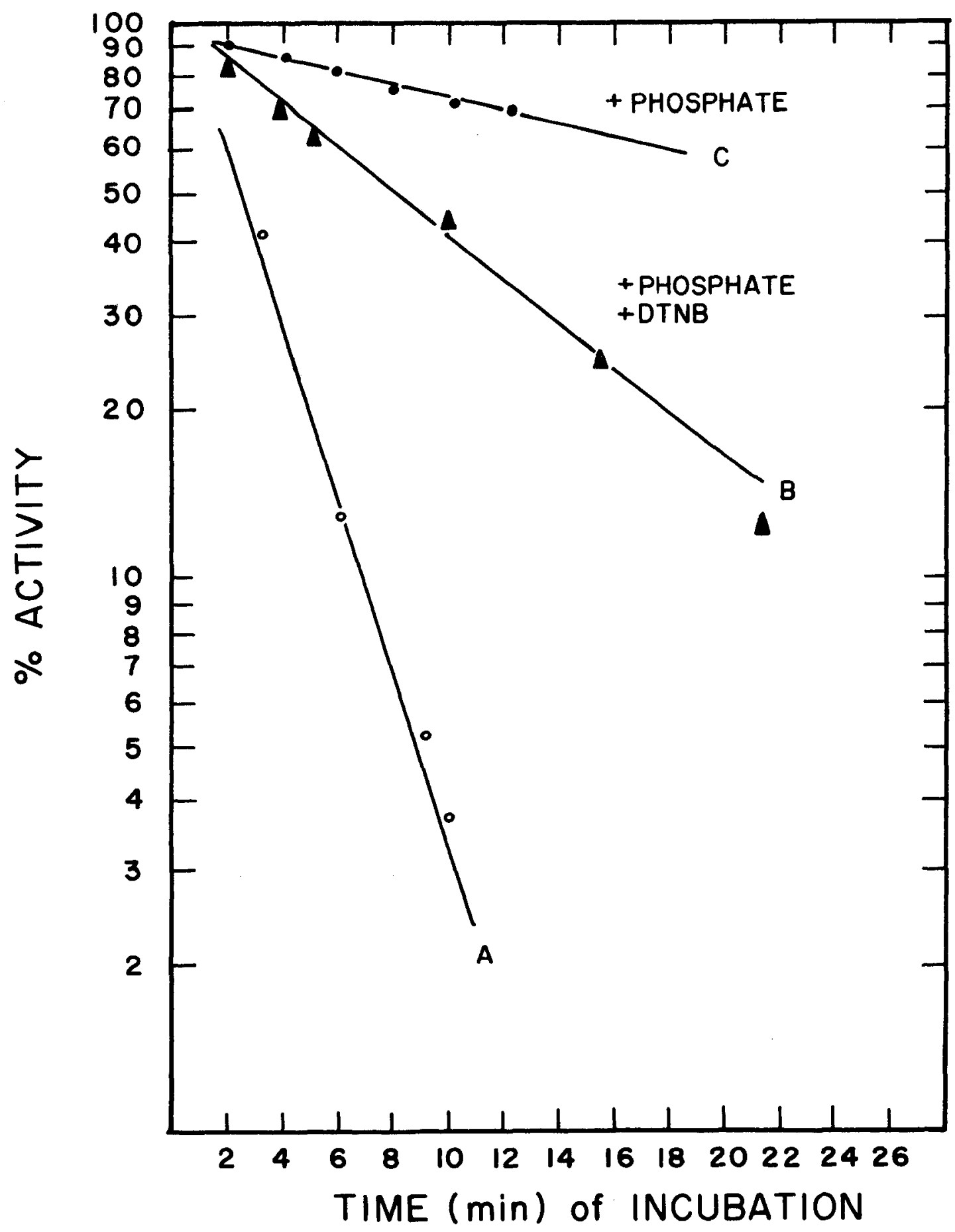


Legend to Figure 5 MDH Activity Loss Compared to SH Appearance in 4 Mrea

Curve A) shows the activity assays (expressed as $10 \mathrm{~g}$ \% activity). Periodic aliquots were removed from SH assay system \# I, $4 \mathrm{M}$ urea, and assayed by following the oxidation of $\mathrm{NADH}$ as described in the methods.

Curve B) represents SH appearance expressed as $10 \%$ \% of unreacted SH groups using SH assay system \# $1,4 \mathrm{M}$ urea. 


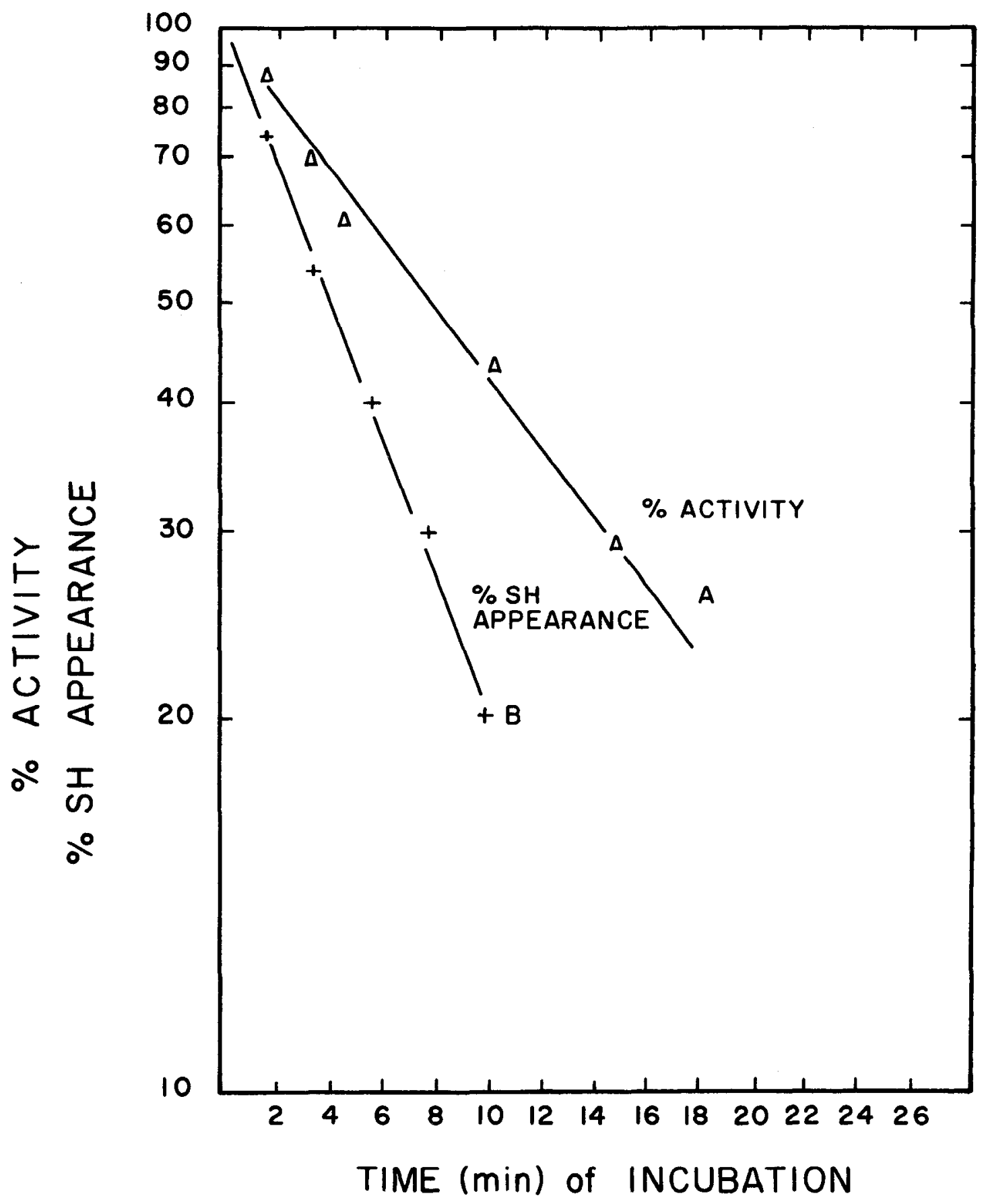


Legend to Figure 6 The Activity of NDH in Urea and Phosphate as a Function of $\mathrm{pH}$

Dialyzed M MDH (commercial) was diluted out to $0.0143 \mu \mathrm{M}$ in various mixtures of $0.1 \mathrm{M}$ potassium phosphate of varying $\mathrm{pH}$ in the presence ( -...-) and absence ( -t-t-) of $4 \mathrm{M}$ urea and incubated for 10 minutes at $25^{\circ} \mathrm{C}$. Aliquots of the incubation mixtures were measured for activity as described in the methods section. The activity is expressed as umoles NADH oxidized per minute.

The individual points are controis diluted and incubated for 10 minutes at $25^{\circ} \mathrm{C}$ in: 1) $16.7 \mu \mathrm{M}$ serum albumin, $0.02 \mathrm{M}$ potassium phosphate, $\mathrm{pH} 7.4$, 2) water, 3) $4 \mathrm{M}$ urea, 4) $0.1 \mathrm{M}$ and $0.01 \mathrm{M} \mathrm{KCl} \pm 4 \mathrm{M}$ urea. 


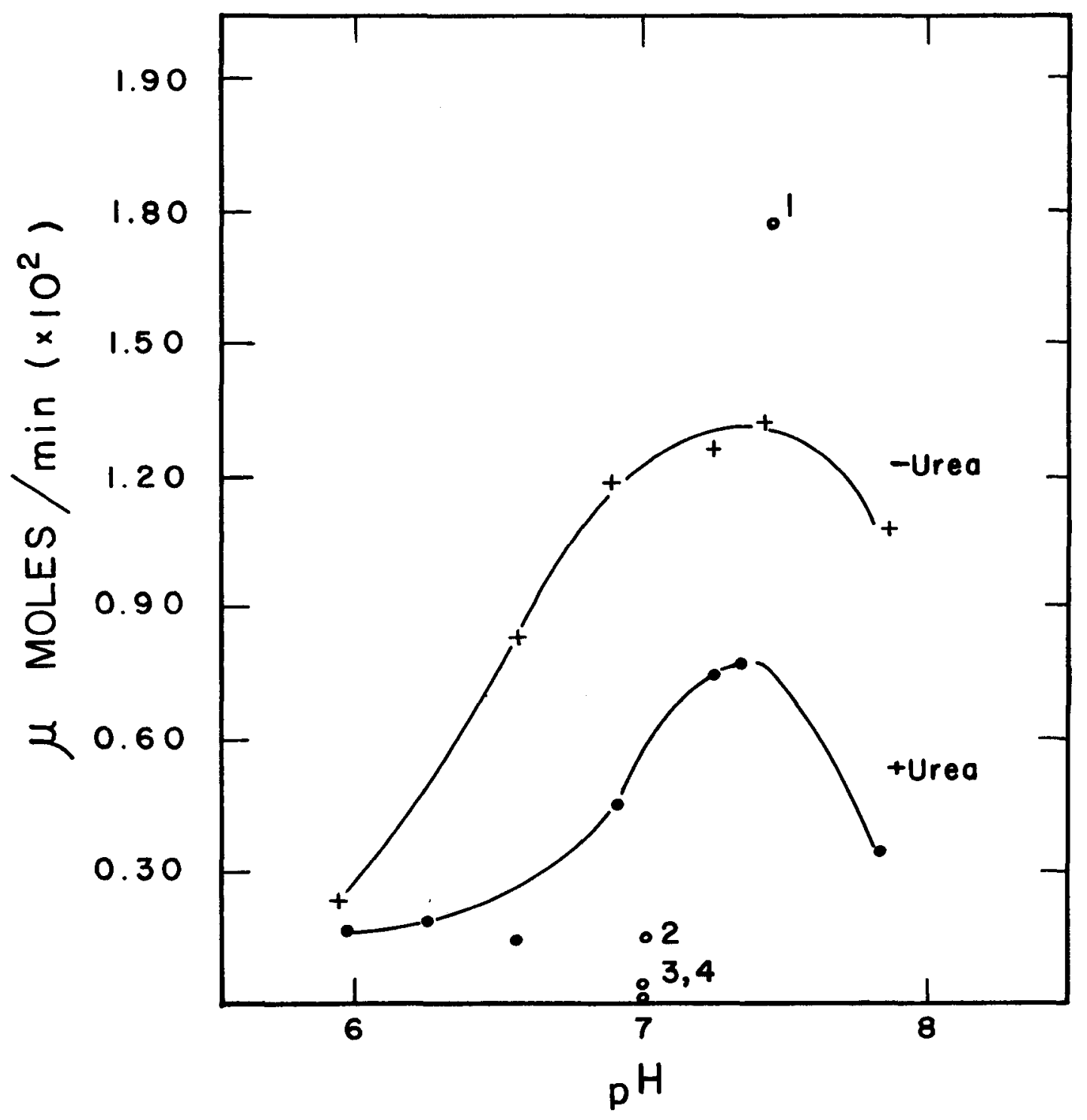

159224

\section{UNIVERSITY OF WINDSOR LIBRARY}


TABLE II

COMPAR ISON OF THE EFFECT OF PHOSPHATE IONS ON SH APPEARANCE AND ACTIVITY LOSS AT HIGHER UREA CONCENTRATIONS

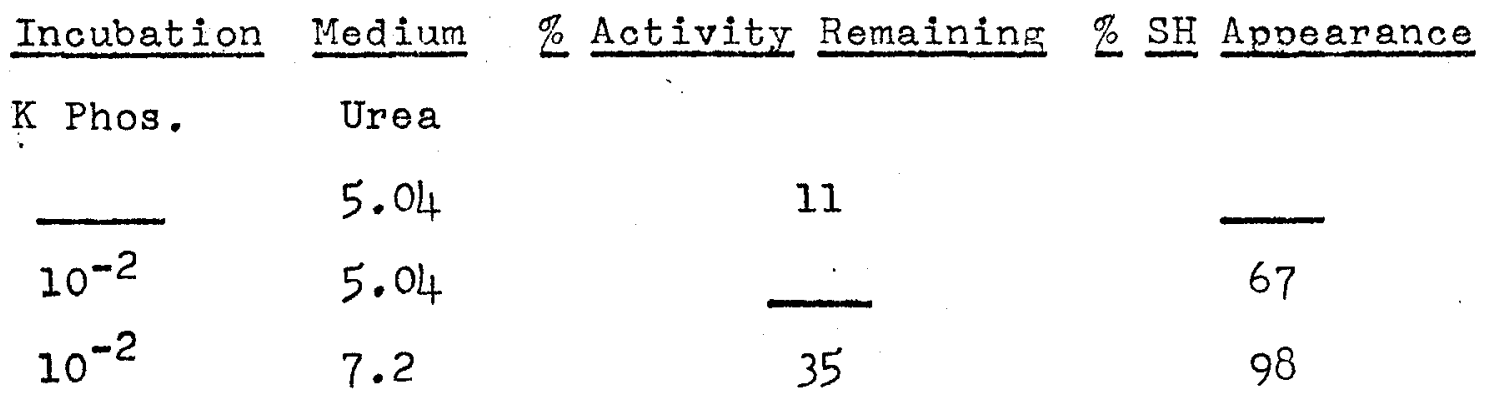

\section{Legend:}

$0.45 \mu M M-M D H$ (commercial) was incubated in the designated amounts of potassium phosphate, $\mathrm{pH}$ 7.4, and urea at $25^{\circ} \mathrm{C}$, and aliquots were assayed for activity as described in the methods after four minutes incubation. $\mathrm{SH}$ assay system \# 1 was used to measure $\% \mathrm{SH}$ appearance using the indicated concentrations of urea and potassium phosphate buffer. 
Legend for Table III Effect of Substrates on Protection of Activity and SH Appearance in 4 M Urea

- M-MDH (commercial) was incubated in two stages. For the first incubation ( 15 minutes, $25^{\circ} \mathrm{C}$ ) the enzyme was incubated in the presence of each substrate neutralized by $\mathrm{KHCO}_{3}$, using $0.163 \mathrm{mM} \mathrm{NADH}, 0.163 \mathrm{mM} \mathrm{NAD}^{+}, 3.8 \mathrm{mM} \mathrm{OAA}$, and $5.0 \mathrm{mM}$ L-Malate.

For the second incubation $\left(15 \mathrm{~min} ., 25^{\circ} \mathrm{C}\right) 10 \mu \mathrm{l}$ aliquots of the above incubates were added to A) SH assay system \# I (- enzyme), $4 \mathrm{M}$ urea (column I) B) SH assay system \# I (- enzyme), $4 \mathrm{M}$ urea, and using $10 \mathrm{mM} \operatorname{Tr} i s-\mathrm{HCl}$, $\mathrm{pH}$ 7.4, instead of potassium phosphate buffer (column II). The final concentration of $\mathbb{M}-\mathbb{M D H}$ (commercial) in each of these assay systems was $0.45 \mu \mathrm{M}$.

The activity data presented here represents tho activity of the enzyme measured by removing aliquots after 15 minutes incubation from the system described in $A$, above. The aliquots were assayed by following NADH oxidation, as described in the methods.

Column III shows the \% SH appearance under slightly different conditions. The first incubation 160 minutes, $25^{\circ} \mathrm{C}$ ) of $\mathrm{M}-\mathrm{MDH}$ (CMC) was carried out in the presence of substrates neutralized by $\mathrm{KHCO}_{3}$, using $0.13 \mathrm{mM} \mathrm{NADH}, 0.13$ $\mathrm{mM} \mathrm{NAD}{ }^{+}, 7.6 \mathrm{mM} \mathrm{OAA}$, and $6.7 \mathrm{mM}$ L-Malate. The second incubation ( 60 minutes, $\left.25^{\circ} \mathrm{C}\right)$ was carried out in the presence of $\mathrm{SH}$ assay system \#2 (- enzyme), $4 \mathrm{M}$ urea, and $1 \mathrm{mM}$ EDTA. The final concentration of M-MDH (CMC) in each assay mixture was $0.314 \mu \mathrm{M}$. 


\section{TABLE III}

EFFECIP OF SUBSTRATES ON PROTECTION OF ACTIVITY AND SH APPEARANCE TN 4 M UREA

First Incubation

Second Incubation in 4 Mrea

$\mathrm{MDH}^{+}$

\% Activity \% SH Appearance

(10 mir IK Phos.)

I II III

$\mathrm{H}_{2} \mathrm{O}$

61

$100100 \quad 100$

NADH

96

$\begin{array}{lll}86 & 87 \quad 85\end{array}$

$\mathrm{NAD}^{+}$

83

$\begin{array}{lll}86 & 77 \quad 85\end{array}$

OAA

94

$\begin{array}{lll}88 & 85 & 83\end{array}$

L-Malate

$\begin{array}{lll}77 & 77 & 87\end{array}$ 


\section{TABLE IV}

SH APPEARANCE IN $4 M$ UREA IN

THE PRESENCE OF NADH

Observed First Order Rate Constant

$$
\text { (41.2 mps) }
$$

NADH

$\min ^{-1}$

0.062

$0.13 \mathrm{mM}$

0.033

\section{Legend:}

M-MDH (CMC) was incubated in two stages. The first incubation ( 1 hour, $25^{\circ}$ C) was in the presence of $\mathrm{H}_{2} \mathrm{O}$ or $0.13 \mathrm{mM} \mathrm{NADH}$ (neutralized by $\mathrm{KHCO}_{3}$ ). Aliquots were removed and added to SH assay system \# 2 (- enzyme), using $4 \mathrm{M}$ urea and $10 \mathrm{mM}$ EDTA. The final concentration of enzyme was $0.314 \mu \mathrm{M}$. This second incubation was carried out for one hour at $25^{\circ} \mathrm{C}$ and followed spectrophotometrically as described in the methods. 


\section{Discussion}

The sulfhydryl groups of pig heart $M-M D H$ are not readily accessible for reaction with DTNB the $S H$ reagent used in this study. Treatment of the enzyme with urea changes the conformation of the molecule in such a way that the SH groups are exposed and react with DTNB. Siegel and Englard (3) reported that beef heart M-MDH would not readily react with p-mercuribenzoate, unless the enzyme was titrated in the presence of urea. The appearance of $\mathrm{SH}$ groups in the presence of urea has an observed first order rate constant as seen in figure one. The observed first order rate constant increases with increasing urea concentration (Figures 2 and 3 ). It was also observed that not all of these sulfhydryl groups of pig heart M-MDH are essential for its activity. This fact is reflected in the non-parallel loss of activity and SH appearance of $\mathrm{M}-\mathrm{MDH}$ in urea solutions (Figure 5).

The SH groups of M-MDH are either "buried" in the folds of the protein or in some way protected against reaction with DTNB. Boyer (8) has suggested that "buried" SH groups are hydrogen bonded to maintain the tertiary structure of the protein. In urea solutions 
these hydrogen bonds would be disrupted and the conformation of the protein would be changed in such a way that the SH groups would be exposed.

- In studies on the activity coefficients of a synthetic peptide in urea solutions (15) Robinson and Jencks found that the activity coefficients of the synthetic peptide and proteins in general decrese with increasing urea concentration. The protein must unfold or open up becoming more and more soluble until it is completely unfolded.

Another possibility is that urea might break the native $\mathrm{M}-\mathrm{MDH}$ molecule down into its subunits. However this is unlikely to take place. Some evidence for the existence of subunits of this enzyme has been presented $(19,20,25,26)$. Thorne, Grossman, and Kaplan (25) have shown that the separation of the components of M-MDH takes place only after long periods of electrophoresis. If the enzyme is pretreated with $6 \mathrm{M}$ urea, the only effect that is noted is a preferential change in the distribution of $\mathrm{M}-\mathrm{MDH}$ components. It has also been reported that subunits of LDH (27) are formed only in solutions of very high urea concentrations (12 M) (5, 28,29). Therefore it seems that at the urea concentrations used in the present study, urea mainly affects the tertiary structure of mitochondrial malate dehydrogenase. 
Titration of the enzyme with DTNB in the presence of urea showed that there were from 10 to 12 sulfhydryl groups per molecule of $\mathrm{M}-\mathrm{MDH}$ (pig heart). This value is in close agreement with the value of 10 to $13 \mathrm{SH}$ groups per molecule reported for beef heart M-MDH by Siegel and Englard (3), who assumed a molecular weight of 65,000 for the enzyme; and, is slightly lower than the 14 SH groups per molecule reported by Thorne and Kaplan (1) for pig heart M-MDH. Such differences are common when comparing values obtained with different SH reagents ( 8$)$.

In $4 \mathrm{M}$ urea solutions with phosphate present the "masked" SH groups can be exposed but the value of the observed first order rate constant decreases with increasing phosphate concentration (Table I). The activity of $M-M D H$, as measured by the number of pmoles of NADH oxidized per minute, is also protected by higher phosphate concentrations (Figure 4). This effect of potassium phosphate on the activity of the enzyme is not due to ionic strength and is only functional in a pH range of 7.0 to 7.5 (Figure 6). Joyce and Grisolia (2) have noted that the addition of inorganic phosphate, during the assay of malic dehydrogenase, markedly stimulated enzyme activity when malate formation was measured. Robinson and Jencks (16) have shown that phosphate ions will salt out a peptide. This would 
have the effect of preserving tertiary structure and thus decreasing the solubility of a protein in urea solution. Thus it seems that the phosphate ion does induce a stabilization of enzyme structure, which in turn preserves enzyme activity.

Phosphate protection of activity and protein conformation takes place oven at higher urea concentrations as seen in Table II. The presence of phosphate ions preserves the activity of the enzyme in $7.2 \mathrm{M}$ urea even when all the SH groups have been exposed. This suggests that the phosphate ions keeps the active site of the enzyme functional even though all of the SH groups have been exposed.

The protection of enzymatic activity by the substrates of $M-M D H$ was studied in the presence of phosphate. NADH, $\mathrm{NAD}^{+}$, and $\mathrm{OAA}$, 2.11 , protected the enzyme against the loss of activity. The reduced form of $\mathrm{NAD}^{+}$, provided greater protection of enzyme activity than the oxidized form. This was also observed for lactic dehydrogenase by Di Sabbato and Kaplan (30).

In the prosence of inorganic phosphate ions or tris-hyarogen chloride, each of the substrates bind to the protein in such a way that about two SH groups per molecule of pig heart $M-M D H$ remain unaccessible to DTNB (Table III). This can mean one of two things.

\section{UNIVERSITY AF WINDSOR LIRRARY}


First, the protection is at the active site; secondly, there is a conformational stabilization of the whole molecule which prevents complete SH appearance, and slows down the loss of activity.

Table IV shows that in the presence of NADH, the observed first order rate constant is much lower than in its absence. This is an indication that NADH stabilizes the protein conformation of the enzyme, slowing down SH appearance. Therefore the effect of $\mathrm{NADH}$ on the enzyme, at the concentrations used, are twofold. First, it prevents total SH appearance; and, secondly, it slows down the unfolding of the protein molecule.

Thorne and Kaplan (1) found that pig heart $\mathrm{M}-\mathrm{MDH}$ binds two moles of NADH per 70,000 grams of enzyme. Thus it is possible that the NADH does in fact bind to the SH groups of the enzyme molecule. Seigel and Englard (3) suggested that $\mathrm{OAA}$ might react with an $\mathrm{SH}$ group essential for activity. It is possible that OAA reacts with protein sulfydryl groups forming a thiohemiacetal or a thiohemeketal (31).

In conclusion, pig heart $\mathrm{M}-\mathrm{MDH}$ is protected against activity loss and SH appearance by phosphate, and the substrates of the enzyme. The evidence presented here points to SH involvement in enzyme activity but more 
work will have to be done to determine the active site and the mechanism of the reaction, which is catalyzed by mitochondrial malate dehydrogenase.

The use of DTNB in these studies has proved to be a very useful tool. The advantage of DTNB over other SH reagents, like p-mercuribenzoate, is the ability of following continuously the kinetics of SH appearance.

A further area to explore would be conformational changes of supernatant (cytoplasmic) malate dehydrogenase with and without urea; and, how potassium phosphate and the substrates of the enzyme would affect its denaturation in urea solutions. Other areas that could be studied with both enzymes are the loss of activity and the $\mathrm{SH}$ appearance as a function of substrate concentration; as a function of pH; as a function of temperature; and, as a function of ions which inhibit as well as others which stimulate enzyme activities. The effects of freeze thawing and lipid protection on protein conformation and enzyme activity could also be investigated, using the DTNB assay for SH appearance. To establish whether dissociation of M-MDH into its subunits takes place in $4 \mathrm{M}$ urea solutions careful ultracentrifuge studies (or other means of accurately determining molecular size) would have to be carried out (32). 


\title{
CHAPTER III
}

\author{
SUMMARY
}

Pig heart $M-M D H$ is inactivated when diluted in water but no sulfhydryl groups are unmasked during a one hour incubation period. However in the presence of urea, the enzyme is inactivated with a concommitent appearance of SH groups. The loss of activity and the appearance of $\mathrm{SH}$ groups do not take place at the same rate. The appearance of $\mathrm{SH}$ groups can be followed spectrophotometrically with the SH reagent DTNB at $412 \mathrm{~m} \mu$. The $S H$ groups are exposed in a first order reaction. Titration of pig heart M-MDH with DTNB in the presence of $4 \mathrm{M}$ urea exposes 10 to $12 \mathrm{SH}$ groups per molecule of the enzyme.

Pig heart $M-M D H$ is partially protected against activity loss and SH appearance by inorganic phosphate ions. Protection against activity loss in the presence of phosphate ions is $\mathrm{pH}$ dependent. The enzyme is also partially protected against activity loss by the substrates $\mathrm{NADH}, \mathrm{NAD}^{+}$, and $\mathrm{OAA}$. Both $\mathrm{NADH}$ and inorganic phosphate ions considerably reduce the observed first order rate constant for SH appearance. The enzyme is protected against complete $\mathrm{SH}$ appearance in $4 \mathrm{M}$ urea solutions by 
the substrates NADH, NAD ${ }^{+}, \mathrm{OAA}$, and L-Malate. Preincubation of the enzyme with the substrates before urea inactivation results in the appearance of about 85 per cent of the SH groups. About two sulfhydryl groups per molecule of pig heart M-MDH remain "buried". 


\section{B IBLIOGRA PHY}

1. Thorne C. J.R. and Kaplan, N. O., J. Biol. Chem., 238, $1861(1963)$.

2. Joyce, B. K., and Grisolia, S., J. Biol. Chem., 236, . 725 (1961).

3. Siegal, I., and Englard, S., Biochim. Biophys. Acta, 64, 101 (iǵ2).

4. Di Sabato, G., and Kaplan, N. O., J. Biol. Chem., 2Llo, 1072 (1965).

5. Bitensky, M. W., Yiolding, I., and Tomkins, G. M., J. Biol. Chem., 2lto, 1077 (1965).

6. Schramm, M., Biochemistry, 2, 1231 (196/4).

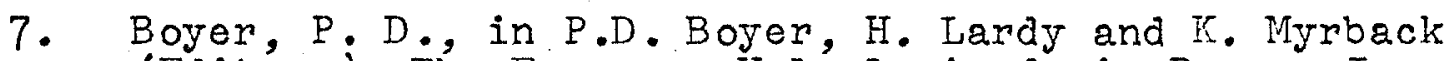
(Editors), The Enzymes, Vol. 1, Academic Press, Inc., New York, 1959, p. 511 .

8. Boyer, P. D., Brookhaven Symp. Biol., 13, 1 (1960).

9. Cecil, R., in H. Neurath (Editor), The Proteins, Vol. 1, 2nd edition, Academic Press, Inc., New York, 1953, p. 380 .

10. Damjanovich, $S_{j}$, and Kleppe, K., Biochim. Biophys. Acta, 122, 145 (1966).

11. Stern, R., De Luca, M., Mehler, A., and Mc Elroy, W. D., Biochemistry, 5, 126 (1966).

12. Li, T., and Vallee, B. L., Biochemistry, L, 1195 (1965).

13. Srere, P.A., Arch. Biochem. Biophys., 110, 200 (1965).

14. Abu-Hamcityah, M., I. Phys. Chem., 69, 2720 (1965).

15. Robinson, D. R, and Jencks, W. P., J. Am. Chem. Soc., 87, 2462 (1965).

16. Robinson, D. R., and Jencks, W. P., J. Am. Chem. Soc., 87, $2470(1965)$. 
17. Grisolia, S., Fernandez, M., Amelunxen, R, and Quijada, C. I.., Biochem. J., 85, 568 (iq62).

18. Warren, J.C., and Cheatum, S.G., Biochemistry, 5, $1702(1966)$.

19. Chilson, 0. P., Kitto, G. B., and Kaplan, N. 0., Proc. Natl. Acád. Sci. U. S., 53, 1006 (1965).

20. Chilson, O.P., Kitto, G. B., Pudles, J., and Kaplan, N. O., J. Biol. Chem., 2lil, 2431 (1966).

21. Ellman, G., Arch. Biochem, Biophys, 82, 70 (1959).

22. Ochoa, S., in S. P. Colowick and N.O. Kaplan (Editors), Methods of Enzymology, Vol. 1, Academic Press, Inc., New York, $1955,0.735$.

23. Kitto, G. B., Private Communication, April 26, 1965.

24. Warburg, $0 .$, and Christian, W., Biochem. Z., 310 , 384 (1942).

25. Thorne, C.J.R., Grossman, I. I., and Kaplan, N. O., Biochem. Biophys. Acta, 73, 193 (1963).

26. Kitto, G. B., Wasserman, P. M., Michjeda, J., and Kaplan, $N .0 .$, Biochem. Biophys. Res. Commun., 22, $75,(1966)$.

27. Markert, C. I., Science, 140, 1329 (1963).

28. McKay, R. H. and Kaplan, N. O., Biochim. Biophys. Acta, 52, 156 (1961).

29. Brand, L., Everse, J., and Kaplan, N. O., Biochem1stry, I. 423 (1962).

30. Di Sabato, G., and Kaplan, N. O., J. Biol. Chem., 232, 438 .

31. Schubert, M.P., J. Biol: Chem, II4, 347 (I936).

32. Kitto, G. B., Private Communication, October 25, 1966. 
1940 Born on April 2, 1940 in Detroit, Michigan, United States of America.

Son of Mr. and Mrs. John B. Seguin.

1954 Graduated from St. Scholastica's Grade School, Detroit, Michigan.

1958 Graduated from Catholic Central High School, Detroit, Michigan.

1959 Professed as a member of the Congregation of the Priests of St. Basil, Pontiac, Michigan.

1960 Promoted from the Freshman Course at the University of St. Michael's College, Toronto, Ontario, Canada.

1964 Graduated from the Honours Chemistry and Biology Program at the University of Windsor, Windsor, Ontario.

1964 Began taking courses for teacher certification at the University of Detroit, Detroit, Michigan.

1964 Began teaching chemistry at Catholic Central High School, Detroit, Michigan. 